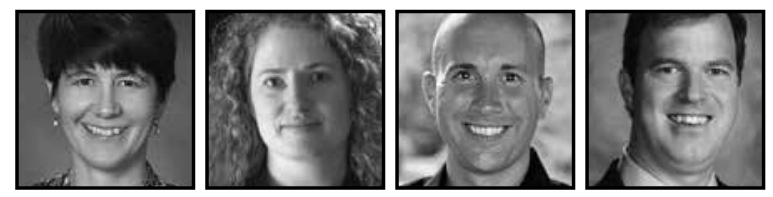

\title{
Teacher Research and Adult Learning in Music Education
}

Colleen Conway, University of Michigan

Erin Hansen, University of Houston

Scott Edgar, Lake Forest College

C. Michael Palmer, Ball State University

\section{ABSTRACT}

The purpose of this study was to describe the experiences of seven music educators who designed and implemented teacher research in their classrooms in relation to the Merriam, Caffarella, and Baumgartner (2007) theory of adult learning. Findings are presented within participant profiles and suggest that motivations to participate included a desire to be a better teacher and an interest in collaborating with the University. The collaboration helped the participants to continue with their studies as did their curiosity about the learning of their students. The issue of time hindered some of the participants' ability to complete their studies.

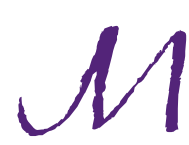

usic education researchers often write about the potential of action research or teacher research' in addressing important issues within the profession (Leglar \& Collay, 2002; Regelski, 1994; Robbins, Burbank, \& Dunkle, 2007; West, 2011). Teacher research is also suggested as a means to connect research and music teaching practice in preservice and inservice music teacher education (Conway \& Borst, 1999; Conway, Eros, \& Stanley, 2009). Miller (1996) posited that teacher research is the most realistic research approach for music teachers because research questions emanate from teachers' work. Conway and Jeffers (2004) discussed the value of collaboration within the teacher research process: 
This research project has been one of, if not the most, beneficial activities I have pursued in my 35 years as an instrumental music teacher. One of the most important reasons for the successful completion of the present project was having a collaborator. Having a partner to critique my work made it much easier to see the progress. Sharing each step along the way made me feel secure about the work I was doing and the direction the project was taking....Being able to share ideas, listen to suggestions, and talk about problems and frustrations made this project exciting and manageable. (p. 39)

However, the music education profession has very little empirical evidence to help professional development providers and teacher educators understand the phenomena of teachers doing their own research. In criticizing preservice and inservice teacher education for lacking theory and overemphasizing "best practice research," Grossman and Schoenfeld (2005) stated:

The [early work in teacher education pedagogy] was grounded not in a well-defined theory of adult learning, but rather in a kind of gritty empiricism, building on what seemed to work and discarding what did not..... In addition to better tools, we need better theory, which is itself a different kind of tool. Such a theory would go beyond the particulars of a specific pedagogical approach to help us understand more broadly the relationship between the pedagogies of professional education and features of professional practice. (p. 450)

In an attempt to provide empirical insight as to the experiences of teacher researchers in music and to respond to Grossman and Schoenfeld's concern about use of adult learning theory in teacher education research, we have conceptualized this study through the theory of adult learning provided by Merriam, Caffarella, and Baumgartner (2007).

\section{Purpose}

The purpose of this study was to describe the experiences of seven music educators who designed and implemented teacher research in their classrooms in relation to the Merrian et al. (2007) theory of adult learning. The key focus was on describing how and why they began, implemented, and completed or discontinued a teacher research project. We considered ourselves (Colleen, Erin, Scott, Michael) to be the adult educators, and the teacher participants were the adult learners. As we examined 
the data and artifacts (lesson plans, P-12 student work, musical scores, etc.) from the participant teacher research projects, we searched for ways in which planning, carrying out, and analyzing their own practice were examples or not of adult learning theory.

\section{Adult Learning Theory}

As defined by Merriam and colleagues (2007), key concepts of adult learning theory include: (a) As people mature, their self concept moves from dependent to selfdirected: (b) adults accumulate a "rich reservoir of experience" (p. 84) throughout their lives; (c) adults focus more on immediacy of application than future application; (d) internal motivation is strong for adults; and (e) adults need to see relevance in order to learn something.

Merriam et al. (2007) differentiate formal learning (in a degree or certificate program) from non-formal learning (organized learning opportunities outside the formal educational system) and informal learning (experiences of everyday living). The work that our participants were doing in their teacher research studies as well as in their collaborative communications for this study is considered "non-formal learning."

Finally, adult learning theory suggests that in order to be successful in their learning, adults need to formulate their own learning experiences with a teacher serving in the role of coach, mentor, or guide (Merriam et al., 2007). The responsibility of adult educators "is to help learners, whether they are learning on their own or in formal learning programs, to be able to plan, carry out, and evaluate their own learning" (p. 107).

\section{Music Education Past Research}

The existing teacher research literature in music education focuses primarily on teachers developing alternative music curricula and assessment activities for their classrooms (Byrne \& Sheridan, 2001; Conway \& Borst, 1999; Conway \& Jeffers, 2004; Miller, 1996). No past studies have examined music teachers' experiences in doing their own research in relation to adult learning. 
Although Standerfer (2008) did not examine teacher research, her investigation of the experiences of three choral music teachers who completed the process of National Board for Professional Teaching Standards (NBPTS) certification in relation to adult learning theory has strong connections to our work. Standerfer framed her study in the adult learning theories of Candy (1991) and Mezirow (1991) and suggested that the process of completing NBPTS certification led participants to experience self-directed learning (Candy, 1991) and transformative learning (Mezirow, 1991). The NBPTS process invites participants to plan, implement, and reflect on their teacher practice in ways similar to the work of our participants in their teacher research studies. Although we did not frame our work within the two specific theories that Standerfer explored, there were elements of self-direction and transformation in the learning of some of our participants that will be apparent in the profiles.

\section{Method}

We approached this investigation using "basic qualitative research" (Merriam, 2009). Merriam suggests:

In my experience, in applied fields of practice such as education, administration, health, social work, counseling, business, and so on, the most common "type" of qualitative research is a basic, interpretive study. One does a qualitative research study, not a phenomenological, grounded theory, narrative analysis, or critical or ethnographic study. Over the years I have struggled with how to label such a study, using words such as generic, basic, and interpretive. Since all qualitative research is interpretive, I have come around to preferring labeling this type of study as a basic qualitative study (bold added). (p. 22)

Participants (see Figure 1 in Profiles) included seven music teachers (all pseudonyms) who designed a research project in their classrooms during the 2010-2011 school years. Detailed profiles of these participants appear in the findings section of this report. Details of the projects appear in the profiles, and procedures for meetings and data collection are provided below.

Our choice of participants represents what Patton (2002) would call criterion sampling. The criteria included:(a) experienced music teachers (5-16 years of teaching); (b) completion of a graduate research course; and (d) a willingness to devote time and energy to teacher research. The sense was that although these participants 
exhibited these unique background characteristics, the profession could learn from these participants.

\section{Data Collection and Procedures}

Project start-up meeting. Each of the seven participants was asked to attend one of two project start-up meetings held in August 2010 (three attended one meeting, and four the other). The meeting introduced the participants to the goals of our study and invited them to begin to share ideas for research projects in their classrooms. Logistics for the email survey, observations, and interviews were also addressed at this first meeting. The meetings were not recorded as we were trying to set up an environment of inquiry and sharing. All co-authors wrote reactions to the meetings in our researcher logs.

Email survey. All seven participants responded to an open-response email survey sent just after the start-up meeting that included the following questions: (a) Describe your current teaching position; (b) How long have you worked in this position?; (c) List previous teaching positions and years occupied; (d) What is your current teaching schedule?; (e) Provide instances in your teaching when you modified instruction based on evidence gathered from your students or classroom; (f) Given the answers above, what were your motivations for examining your classroom or teaching?; (g) What are some of the issues, curiosities, or concerns you have regarding your teaching this year?

Classroom observation. Each participant was visited once by one of the co-authors in Fall 2010. Observations provided a context by which to interpret other data from the participants. Field notes from the observations were collected.

Individual interviews. Each participant was interviewed once by one of the co-authors in Fall 2010. The fall interview was held on the same day as the fall observation in October or November 2010. Much of this interview focused on follow-up to the email survey and discussion of the purpose and design of the research projects to be done by the participants. A second interview was held in May or June of 2011 that focused on implementation and completion of the projects. The same interviewer did the second interview. Both interviews were approximately 30 minutes. All interviews were audio-recorded. ${ }^{2}$

Focus group interview. One focus group meeting was held in June with four participants. The remaining three participants participated in individual interviews that same month. The focus group gave the four participants who were able to attend 
an opportunity to elaborate on issues they discussed in individual interviews and to respond to one another in a group format. All four researchers were at the focus group meeting. The focus group meeting was audio-recorded. The individual interviews with the other three participants also allowed them to expand on responses from earlier interviews and were also audio-recorded.

Artifacts from the participant projects. In some cases the researchers collected lesson plans, musical scores, P-12 student assignments, audio recordings, surveys, and PowerPoint presentations associated with the projects. These served as a secondary data set and helped us to understand the teacher research projects of the participants.

Research team communication log. The four researchers kept a log of all email communication with participants as well as a running list of thoughts about the study that were prompted by phone or in-person interactions with the participants or with one another. This log was used a source of triangulation.

\section{Analysis}

Using the key elements of the Merriam et al. theory (see Appendix A) as initial codes, recordings from individual interviews were analyzed by at least two researchers (in separate analysis). All four researchers were involved in this process and interviews were divided between us. Erin, Scott, and Michael analyzed the interviews they had conducted as well as the interviews of two other participants. Colleen analyzed five interviews not covered by the others. The interview data provided the primary data. The research team met several times to discuss the codes. We then chose to create profiles of each participant written by the researcher who had observed and interviewed that person. Profiles were written based on the research questions and we began to formulate common themes that emerged in multiple participants (see Appendix A). Other data sources (start-up meeting, observations, focus group interviews, project artifacts, and researcher logs) were used as secondary sources to provide context for the researchers as they wrote the profiles and formulated the themes. Each participant was sent the written profile via email and was invited to add or delete from the profiles; however, no changes were suggested for this member-checking process. 


\section{Findings}

We begin with a graphic of participants for reader ease and then narrative participant profiles that include participants' general thoughts about teacher research. Common themes are then presented with evidence from the data in the areas of: (a) Motivated to become a better teacher and wanting to know more about their students; (b) Motivated to present at the upcoming state conference; (c) University collaboration; and (d) Concerns regarding time. Finally, we connect the experiences of these music teachers back to Merriam et al.'s key concepts of adult learning (see Appendix A). Participant responses are always presented in the order they appear in Figure 1, organized by teaching grade level and music content area.

\section{Findings-Participant Profiles}

\begin{tabular}{|c|c|c|c|c|}
\hline NAME & $\begin{array}{l}\text { TEACHING } \\
\text { LEVEL }\end{array}$ & $\begin{array}{l}\text { YEARS } \\
\text { TEACHING }\end{array}$ & $\begin{array}{l}\text { TYPE OF MUSIC } \\
\text { CLASSROOM }\end{array}$ & TEACHER RESEARCH PROJECT \\
\hline Lilly & $\mathrm{K}-5$ & 4 & General music & Composition in 3rd grade \\
\hline Joe & $\mathrm{K}-5$ & 8 & General music & $\begin{array}{l}\text { Strategies for working with } \\
\text { children w/ Autism Spectrum } \\
\text { Disorder }\end{array}$ \\
\hline Steve & $6-8$ & 12 & Band & $\begin{array}{l}\text { Music theory - student } \\
\text { perceptions of learning }\end{array}$ \\
\hline Mike & $6-8$ & 5 & Band & $\begin{array}{l}\text { Use of instructional time in } \\
\text { rehearsal }\end{array}$ \\
\hline Ann & $6-8$ & 12 & Orchestra & $\begin{array}{l}\text { Strategies for developing } \\
\text { student ownership in class }\end{array}$ \\
\hline Ted & $9-12$ & 7 & Band & $\begin{array}{l}\text { Student-led ensemble } \\
\text { sectionals }\end{array}$ \\
\hline Hannah & $9-12$ & 16 & $\begin{array}{l}\text { Band and } \\
\text { Orchestra }\end{array}$ & $\begin{array}{l}\text { Rhythm development in the } \\
\text { instrumental rehearsal }\end{array}$ \\
\hline
\end{tabular}

Fig. 1: Teacher participants 


\section{Lilly}

Lilly was an elementary general music teacher with five years of experience and teaching in the same district as her husband, Mike (also a participant in this study). Her teacher research project involved looking at how she teaches music composition to her third graders. She designed five composition projects, each influenced by her reflection of how the previous one went and adding musical constraints with each subsequent project. She was very excited about the idea of change and research:

I definitely wanted to change, but never really done a study before. There are always things that I'm saying what can I do, how can I improve? How can I change it, and then going back and looking at the lesson? Where do I want to go, why didn't it work, and why aren't I getting the results I want? I just had to come up with a new direction to take them. (interview, 10/2010)

Lilly believed that doing teacher research was a transformative activity:

I think it's more important than I ever realized. Doing the research I made a true change in my teaching that will affect my career forever. Had I not been able to critically look through that lens, I don't think I'd been willing to take the risk to do it, and to push it as far. (interview, 7/2011)

She needed to get over the initial fear of conducting research, but after she had, it just felt like "good teaching." "Using the term research scares people. But I think it's so necessary. It's changed my teaching forever, and had I not done it, I would still be in my little tiny box" (interview, 7/2011).

\section{Joe}

Joe was in his second year of teaching kindergarten through fifth grade general music at the time of this study. He had an open and amiable personality that seemed to fit his work with young students, further reinforcing his decision to move from directing 5-12th grade band, which he had done for six years. When Joe accepted his current teaching position, he was informed that he would have a music class whose population would be made entirely of students who had Autism Spectrum Disorder (ASD). He went from feeling scared and unprepared to teach such a class to exclaiming that this class "is the highlight of my week!" (interview, 9/2010).

Joe stated the purpose of his study was to learn how to have his students with ASD communicate with him musically. As a result of his data collection and reflection, 
Joe modified his lessons, allowing him to try different and new activities. When asked what motivated him to continue to work on this project, Joe responded with:

The kids. There are many music classes with that population of learner where the only sounds come from me. You can tell they're soaking it in. They can give you that look. And when they do give something back or give some type of reciprocal musical answer or musical idea back to you, it's really motivating when that happens because, for some of them, it's very far and few between. (interview, 6/2011)

\section{Steve}

Steve had 12 years of experience as a middle school band director. Following his school's promotion of formative assessment methods and his own belief in studentcentered learning, Steve regularly surveys his students to determine how to modify and improve instruction. "I always try to get feedback on a project to see if they liked it, what could have gone better, what could have my instruction done better with it" (interview, 11/2010). "There is so much ground to cover in the topic of music, so getting opinions of students can be valuable in keeping student interest" (survey).

For his project, Steve created a questionnaire for his eighth grade band students asking for feedback regarding his use of theory, composition, and music history lessons during band rehearsal. The results corroborated his assumption that the lessons were perceived as valuable to their music education.

It's just real interesting to see what middle schoolers think and what's important, what they value. They want to find out new things, that's what they want to do, compose or research, a lot of them had said something to that effect. (interview, $6 / 2011)$

Having documented evidence for the value of a comprehensive music curriculum is also a motivator for Steve. He thinks his data would be valuable to share with his district colleagues as well as the administration, which is focused on reviewing teachers' scope and sequence in the curriculum. "I want to be able to show them that it is essential to do more of this than just the performance, which has been a struggle" (interview, 6/2011).

\section{Mike}

Mike teaches middle school band in mid-Michigan. The study was his second year in that position and he previously taught middle school band in another district. Mike was 
one of the most enthusiastic participants about doing the study. His enthusiasm in the January focus groups led him to say, "I want to study it all!" Mike began with a study comparing traditional methods of counting rhythms and different syllable choices to a broad study of the use of rehearsal time. The final project involved Mike keeping a detailed record of rehearsal activities and the amount of time spent on each. The process influenced his lesson planning and teaching. Mike had thought about changing teaching practice, but has never considered it research. "I've probably done something in the past where I've brought a new idea or something; I guess I've never thought of it as a study" (interview, 10/2010). Most of his inquiry "stemmed from me having a problem in my class" (interview, 10/2010). He was still getting used to teaching middle school and saw this study as means to help him continue this process: "As I continue to get used to teaching middle school, I am continuously modifying how I do things to make my lessons more middle school applicable" (survey). Overall, his thought about the study was: "I just think it was a guy in a classroom trying to make things go a little better" (interview, 7/2011).

\section{Ann}

Ann had taught elementary and middle school string orchestra for 12 years, nine of which in her current school district. Ann is thoughtful, articulate, and clearly displays a passion for teaching. In an effort to help guide her eighth grade students' reflections of their class experiences, Ann wanted to create a short questionnaire for them to answer once or twice per month. After approximately four months of reflection, Ann then wanted to examine her students' comments and class behaviors to see if there is a change in how they approach music learning. Ann did not complete her project and this is discussed in the "Concerns Regarding Time" section later in the paper.

\section{Ted}

Ted was the director of bands at a large suburban high school. With seven years of teaching experience he was reflective of his teaching practices and was searching for strategies to better his teaching. He was interested in the concept of research and enjoys "speaking research." He spoke of two parts of his brain, the practitioner side and the researcher side: "Working with you [Scott] and Colleen is like working out of a different part of my brain. There's the teaching brain and the research brain" (interview, 1/2011). Ted's research project started out looking at the value of chamber ensembles and morphed into how students can be taught about student-run sectionals. ${ }^{3}$ 
Ted and his wife discovered they were pregnant. Due to the new life circumstances and other stresses of his job, Ted found it difficult to stay committed to his project. He was given opportunities to pull out of the study, but insisted that he stay on at a lesser level of commitment. His final project involved implementing student-run sectionals without the formal instructional sessions.

I think it was beneficial, but not as beneficial as if I did the original plan. I think those younger players seeing the older players run sectionals, in years to come, if I ask one of them to run sectionals, they might remember those attributes and get effective results. (interview, 6/2011)

\section{Hannah}

Coming from a successful 14-year career as a band director at the middle school level, Hannah began teaching high school band and orchestra two years ago. The change in teaching levels and the diversity of teaching duties has challenged Hannah, and she sees the opportunity of doing research in her classroom as a way to gain perspective and a sense of direction for her program.

[Doing research my own classroom] is exciting to me because it's another way for me to look at what I'm doing and trying to get a direction. But it's also frightening that you're looking at what you're doing and evaluating —is it working? - and kind of keeping yourself honest about what you're doing. (interview, 10/2010)

Through our interviews, Hannah was able to identify an area she would like to study. "One thing that I have been really interested in and did a lot of at the middle school is to try to bring music theory into the performing classroom because we don't have a music theory class here" (interview, 10/2010). She wondered, "How does understanding of music theory affect performance? How can theory be incorporated without taking away from rehearsal time?" (survey).

Hannah's original research idea "morphed" over time. Originally interested in rhythm and intonation, her discussions with the research team led to focusing on pulse. She incorporated new exercises, such as walking and playing. "I started noticing that there was a connection between counting and feeling" (interview, 5/2011) and students began moving more as they performed in their seats. Seeing the response in her students' playing and hearing their requests for more movement exercises were motivators to continue the exercises for several months. Thinking about pulse 
drove my lesson planning and it drove what my assessment was and what I was looking for. It made me think a lot more about what it is that they're not understanding and how can I get to that in different ways. (interview, 5/2011)

\section{Findings-Common Themes About Teacher Research}

\section{Motivated to Become a Better Teacher and Wanting to Know More About Their Students}

All of the participants expressed interest in doing teacher research as a way to become a better teacher and many of them framed this within a desire to learn more about their students. Lilly said:

Every year when I look back I just never feel like I've hit the mark on what I wanted to accomplish. Although my students are always better than previous year's students I am always looking for the next thing. There is a lot I need to improve on and I'm hoping this will hold me accountable for doing that his year. (survey)

As a result of implementing composition and this study, Lisa stated, "I feel more confident now than I've ever felt that I'm sending musicians out into the world" (interview, 7/2011).

Joe stated that he was interested in participating in the study because, "I want to know how I can best serve my students" (interview, 9/2010). As part of his work in middle school band, Steve has enjoyed introducing students to music theory, composition, and music history to help them experience music on a deeper level. He said:

I'm really interested in finding out if they value the extra things that we do.... So I want them, you know I want to know if they are relaying [the study of theory] to the music now, and if I were to go through and do some score study and show them the chord progressions, and play it if that helps them to understand it... (survey)

Steve recognizes the value of investigating his students' perceptions about their class experiences. Hearing what they have to say is a motivator for changing his teaching practice. "Right now, we're implementing these common assessments between our two middle schools [on a quarterly basis]. So, it is helping me figure out how to hit what was important to [students] and keep it consistent" (interview, 6/2011). 
Mike suggested:

I don't care how long I do this, or how long I do anything, I always try to... make my wheel a little rounder or spin faster. I'm always trying to get better at everything I do. I don't consider [this study] a leap or a bound. It's just a little baby step...In the big picture, if you can find small manageable things like this, it just makes you a better teacher. (interview, 7/2011)

When Ann was asked why she was motivated to join this project, she stated, "I am motivated by a desire to teach more effectively and to have students learn in such a way that they become independent with their skills and conceptual framework" (survey). All of Ted's teacher research ideas were guided by the motivation to provide "the most meaningful class (artistically, intellectually, etc.) for his students" (survey). Hannah's overall goal as a teacher was stated as: "to improve ensemble sound and deepen their knowledge of music, because I think kids who have more of an understanding are going to hold onto it for life more than those that just experience it on a surface level" (interview, 10/2010).

Hearing that a desire to learn more about students and become better teachers was a strong motivator for our participants, was not surprising given the volunteer sample. Professional development providers for music teachers should continue to consider how to capitalize on teachers' interest in students and work to provide opportunities for music teachers to explore reflection on music student learning through extended professional development. Although this move beyond "one shot" professional development has been regularly suggested in music education (Conway, 2007, 2011), it is still not the norm for music teachers.

\section{Motivated to Present at the Upcoming State Conference}

Two of the participants (Joe and Steve) were giving presentations at the state music conference in January and this presentation was a primary motivator for studying their classrooms from September to January. Joe was to present a session at the state's annual music educators' conference and believed that his preparation for the presentation would also contribute to this study: "Kill two birds with one stone" (interview, 9/2010). For the 2011 state music educator conference, Joe presented teaching techniques that he discovered to be successful with his students to other teachers who might also work with students with ASD. Joe continued to work on his research project after his conference presentation, though he did not collect additional video footage. When asked how his presentation and research project intersected, Joe responded 
by saying that the conference was something in the middle of "one big, long process" (final interview, 6/2011).

For this study, Steve continued with practices he normally uses in assessing student learning and his own teaching methods. Yet, the difference was in documenting these assessments so that he could modify his teaching and share his findings with others through a district-level workshop, state music conference, or music education journal.

The need for music teachers to have opportunities to share their practices with one another has also been suggested in past music professional development literature. However, as with the case against "one shot" programs already mentioned, few opportunities to share promising classroom practices exist for music teachers (Conway, 2007, 2011). Music teacher conferences often focus a great deal on techniques for creating better sounding secondary ensembles that can sometimes be at odds with student-centered teaching practices.

\section{University Collaboration}

All of the participants valued the collaboration with the University that this project created. This concept of "University Collaboration" emerged as an important theme within the profiles. It is hard to know whether participants would have been as diligent in their teacher research work without it. Conway and Borst (1999) suggest: "It may be difficult for K-12 music teachers to find time to design and implement research. However, collaboration with the university professor, for whom research is part of the job expectation, makes equal-partner action research a possibility" (p. 3).

Lilly found many benefits in the university/school collaboration: "I think having you [Scott] point out what I don't see, because I'm in it all the time. Different aspects of the questions, different angles we can take. I think that's really helpful" (interview, 10/2010). A motivator for Steve in completing this project was the collaboration with the University. Asked if he would have conducted this study on his own, he said, "Probably not. You're doing the research and you know the terminology that scares everyone away, and ou know the collection and the analysis. That's the scariest part, I think, about doing something like this, is analyzing it." Having help from the University in designing the research study and helping with questions along the way was fundamental to Steve successfully completing his project.

The collaborative aspect of this study was one of the most beneficial aspects for Mike: "You really influenced me in taking this in a different direction. I don't know if I 
would have done that on my own. Just being a part of something was a lot of it too" (interview, 7/2011). Ted stated personal and professional benefit from the collaboration of the study.

The reason why I wanted to do this was feeling so invigorated and feeling alive. Not being static in my profession. Sometimes when I see an e-mail from Colleen. I say, you know what, don't get stuck in a rut. Keep things going, keep things fresh. Observe your teaching. Try to make it better. I felt that way when I got an email from you [Scott] too. When I saw e-mails from you, I said come on, try to get this done, Ted. I saw an e-mail from you going into a lesson. I taught better that lesson. (interview, $6 / 2011)$

The need for collaboration appears as somewhat of a problematic finding as the resources needed to create and maintain this type of collaboration are considerable. It is unrealistic to think that faculty and graduate students in other institutions could regularly spend the amount of time that we spent on this project. Our project included seven teachers, three doctoral students, and an experienced faculty member. With focus group meetings, travel, and so on, the study was a tremendous expense in terms of time and money.

\section{Concerns Regarding Time}

All seven participants discussed busy lives and difficulty in sticking to schedules. For Ann, Ted, and Hannah the issue of time made completion of the teacher research project they originally designed impossible. Though Ann seemed to regularly reflect on her teaching practice and classes, right from the very beginning she was reluctant and nervous to entirely commit to the research project. Based on comments made during a focus group meeting and an individual interview, it seemed as if Ann was worried that this project would take time away from other tasks: time she did not have to give. After school ended, Ann expanded on her motivation to continue with the project even though it was difficult:

I feel like I want there to be a record, in the world, of how busy teachers are and how we aren't given enough professional time to really do our own....curiosities. We just sit through these professional development days, which are highly structured, which somebody's talking to us about what they've thought about. (final interview, 6/2011) 
Ann explained that she wanted an excuse to legitimize taking time for herself and selfreflection. In the end, Ann did not create or distribute her questionnaire; she felt that she did not have time to construct such a tool, especially since she felt she was spending all of her free hours developing a class website. Ann toyed with the idea of monitoring how her students and their parents used the website and using this information as her research study, but feeling overwhelmed, Ann ultimately discarded this idea.

Ted would have liked to implement his original ideas regarding preparing students for student-led instrumental music sectionals, however, school and life circumstances inhibited this:

I feel guilty that I couldn't take it a step further. Towards myself, my own teaching, my own professional development. I don't ever want to be static. It's easy to fall back on the excuse that life happens. I've got a pregnant wife, extra-curricular conducting obligations, the thing is, once you turn static in this profession, student learning is compromised. I feel guilty that I couldn't find a way to do this more formally. (interview, 6/2011)

When concert time rolled around, however, Hannah went into concert mode (spending most class time in teacher-directed rehearsal) and stopped her movement exercise teacher research project, to both her and her students' dismay. It seemed that the study of pulse and her experimentation in the classroom was energizing and provided a sense of direction in her teaching.

I mainly looked at it as something to get me going in a direction that I felt wasn't there. With this being my third year in the high school, I still felt that I was still looking for my direction. (interview, 5/11)

Yet, the demands of the concert schedule superseded her continued experimentations with pulse.

Although with a sample size of only seven teachers it is not reasonable to state generalizations, it is interesting to note that the largest issues of time were faced by the secondary music ensemble teachers. It may be that the performance requirements of the secondary music classroom make initiatives such as teacher research harder to manage. 


\section{Return to Adult Learning Theory}

Considering these findings within the framework of adult learning theory described in the opening of this paper, it does appear that conducting teacher research is perceived as an adult learning activity. In considering the seven teacher participants as "adult learners" and their experience in the study as non-formal learning, there are several intersections between the experiences of our participants and key features of adult learning theory (Merriam et al., 2007). Features that were mentioned in the opening of the paper are discussed here in the context of this study.

As people mature, their self-concept moves from dependent to self-directed. Our participants were positive regarding the freedom they had in designing and planning their projects. These projects were separate from other adult learning that was being provided by their schools in terms of professional development, so we might suggest they were not "dependent" on their schools, but more self-directed in taking on this project. This finding connects to Standerfer's (2008) work with music teachers regarding positive reactions to programs requiring self-direction.

Adults accumulate a "rich reservoir of experience" throughout their lives. Our data suggest that these teachers' "rich reservoir" of experiences had prompted a wealth of research ideas, but that it was difficult to stay focused on one. These music teachers were so curious about their practice (many "rich" ideas) and yet had had little past research experience to study those topics, thus, for many of them it was hard to know what to study. In some cases their previous experiences ("rich reservoir") led them to fear the concept of research and this fear inhibited their ability to complete the project as completely as they were hoping to.

Adults focus more on immediacy of application than future application. This feature of adult learning also may have made staying focused on research projects more difficult for our learners. Music teachers are very busy and immediate needs such as performances, festivals, assessment, and advocacy for music often made teacher research difficult. We believe that the immediate needs of their classrooms made it harder for teachers to decide on and stick to one particular research topic.

Internal motivation is strong for adults. The very fact that our participants were willing to take part in a study of teacher research suggested they are internally motivated. In addition, all seven participants stayed involved throughout the year despite some disappointment with lack of progress and we believe this represents their internal motivation as well. 
Adults need to see relevance in order to learn something. We examined this issue of relevance in a separate investigation that focused on teacher research as a professional development activity (Conway, Edgar, Hansen, \& Palmer, 2013). In that paper we provide evidence that some of the teacher participants viewed teacher research as a relevant professional development activity and thus were able to learn.

\section{Conclusion}

We need a much deeper and broader base of research before the education profession can suggest the adult learning power of teacher research for music educators. Some of our participants experienced some of the transformative learning referred to in the music education professional development literature (Standerfer, 2008), but it is hard to measure and evaluate this learning. This investigation leads us to propose the following areas of inquiry for future research: (a) How does collaboration with faculty and/or colleagues interact with the learning of teachers doing research?; (b) What types of preparation or inservice might be most useful for teacher researchers?; and (c) What practices might support teacher researchers in their work? The adult learning theory of Merriam et al. (2007) was used as a framework for this inquiry; future researchers might examine other adult learning theories as well as other theories of motivation, collaboration, and teacher learning. We were inspired by the work of our participants and we hope their stories as told in this paper will inspire other researchers to collaborate with teachers to bridge the gaps between music education research and practice as well as consider the use of research to provide for inservice music teacher learning.

\section{Appendix A}

\section{Initial Coding Scheme}

Codes from Adult Learning Theory (Merriam, Caffarella, \& Baumgartner, 2007):

- as people mature, their self-concept moves from dependent to self-directed

- adults accumulate a "rich reservoir of experience" throughout their lives

- adults focus more on immediacy of application than future application

- internal motivation is strong for adults

- adults need to see relevance in order to learn something 


\section{Categories of Emergent Themes}

- wanted to become better teachers/wanted to know more about their students

- preparing for conference presentation

- university collaboration

- concerns regarding time

\section{Notes}

1. Action research and teacher research are considered synonymously for this paper. See Robbins (2014) and West (2011) for a discussion of the subtle differences between these terms and their uses in music education. We use the term "teacher research" to refer to all types of "practitioner inquiry" (Robbins, 2014).

2. Ann's first interview was not recorded due to technical difficulties in the attempt to record.

3. The term "sectionals" is used in music performance classes to refer to small group work with like instruments or voice parts (i.e., flute sectional).

\section{References}

Byrne, C., \& Sheridan, M. (2001). The SCARLATTI papers: Development of an action research project in music. British Journal of Music Education, 18(2), 173-185.

Candy, P.C. (1991). Self-direction for lifelong learning. San Francisco: Jossey-Bass Publishers.

Conway, C. M (Ed.). (2007). Setting an agenda for professional development, policy, practice and research in music education. Journal of Music Teacher Education, 17(1), 56-61.

Conway, C. M. (2011). Guest Editor introduction to symposium on music teacher professional development. Arts Education Policy Review, 112(2), 55-59.
Conway, C. M., \& Borst, J. (1999). Action research in music education. Update. Applications of Research in Music Education, 19(2), 3-8.

Conway, C., Edgar, S., Hansen, E., \& Palmer, M. (2013). Teacher research as professional development for P-12 music teachers. Music Education Research. doi: 10.1080/14613808.2013.848850.

Conway, C. M., Eros, J., \& Stanley, A. M. (2009). Perceptions of master's graduates regarding the effects of the master of music in music education program on P-12 teaching practice. Research Studies in Music Education, 31(2), 1-13. 
Conway, C.M., \& Jeffers, T. (2004). The teacher as researcher in beginning instrumental music. Journal of Music Teacher Education, 22(2), 35-45.

Grossman, P. (2005). Research on pedagogical approaches in teacher education. In $\mathrm{M}$. Cochran-Smith \& K. Zeichner (Eds.), Studying teacher education: The report of the AERA panel on research and teacher education (pp. 425-476). Washington, DC: American Educational Research Association.

Leglar, M., \& Collay, M. (2002). Research by teachers on teacher education. In R. Colwell \& C. P. Richardson (Eds.), The new handbook of research on music teaching and learning (pp. 855-873). New York: Oxford University Press.

Merriam, S. M. (2009). Qualitative research: A guide to design and implementation. San Francisco: Jossey-Bass.

Merriam, S.B., Caffarella, R.S., \& Baumgartner, L. M. (2007). Learning in adulthood: A comprehensive guide (3rd ed.). San Francisco: Jossey Bass.

Mezirow, J. (1991). Transformative dimensions of adult learning. San Francisco: Jossey-Bass.
Miller, B.A. (1996). Integrating elementary general music: A collaborative AR/TR study. Bulletin of the Council for Research in Music Education, 130, 100-115.

Patton, M. Q. (2002). Qualitative research and evaluation methods (3rd ed.). Thousand Oaks, CA: Sage Publications.

Regelski, T. A. (1994). Action research and critical theory: Empowering music teachers to professionalize practice. Bulletin of the Council for Research in Music Education, 123, 63-89.

Robbins, J. (2014). Practitioner inquiry. In C. M. Conway (Ed.). Oxford handbook of qualitative research in American music education (pp. 186-208). New York: Oxford University Press.

Robbins, J., Burbank, M. K., \& Dunkle, H. (2007). Teacher research: Tales from the field. Journal of Music Teacher Education, 17, 42-55.

Standerfer, S. (2008). Learning from the national board for professional teacher certification (NBPTS) in music. Bulletin of the Council for Research in Music Education, 176, 77-88.

West, C. (2011). Teacher research and professional development. Arts Education Policy Review, 112(2), 89-94.

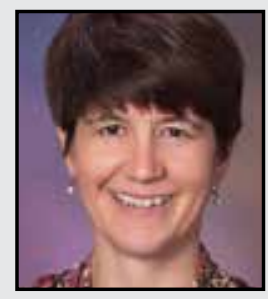

Colleen Conway is Professor of Music Education at The University of Michigan. She has published over 80 research articles in all of the major music education journals. Book publications include: Great Beginning for Music Teachers: A Guide to Mentoring and Induction (MENC, 2003); Handbook for the Beginning Music Teacher (GIA, 2006); Teaching Music in Higher Education (Oxford, 2009); Handbook for the Music Mentor (GIA, 2010); Handbook of Qualitative Research in American Music Education (Oxford, 2014). Her new book, Curriculum and Assessment in Music Education, will be released by GIA in 2015. She is Editor-in-Chief of Arts Education Policy Review and serves on the Senior Editorial Board of Oxford Research Review. 


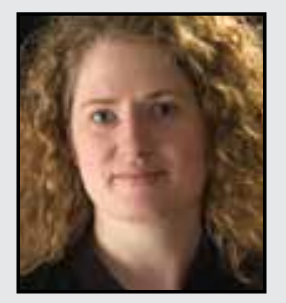

Erin M. Hansen is Assistant Professor of Music Education at the University of Houston. Erin previously taught 5-12 orchestra, several fiddle ensembles, and class guitar for Ann Arbor Public Schools and Saline Area Schools in Michigan for over 10 years. Erin also served on the Michigan board for the American String Teachers Association for six years while acting as program director for the MASTA Elementary String Camp. Erin holds a bachelors degree from Michigan State University, MM from the University of Michigan, and is currently completing her $\mathrm{PhD}$, also from the University of Michigan.

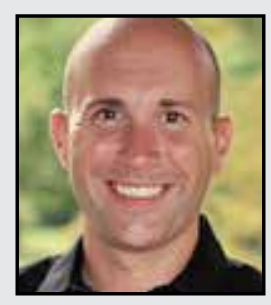

Scott Edgar is an Assistant Professor of Music and Music Education Coordinator at Lake Forest College in Illinois. He received his Doctorate of Philosophy in Music Education from the University of Michigan, his Masters degree in Education from the University of Dayton, and his Bachelor of Music in Music Education degree from Bowling Green State University. His previous teaching experience in higher education includes work at Adrian College in Adrian, Michigan and Concordia College Ann Arbor.

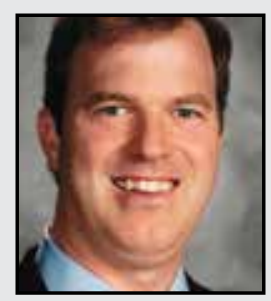

C. Michael Palmer is an Assistant Professor of Music Education at Ball State University in Indiana. Prior to this position, he taught middle and high school instrumental music in California, Indiana, Michigan, and North Carolina. Dr. Palmer has presented clinics at state music education conferences in California, Indiana, and Michigan, as well as national conferences. His scholarly work has appeared in College Music Symposium, the Journal for Music Teacher Education, Music Education Research, and UPDATE - Applications of Research in Music Education. He holds degrees from the University of Michigan (PhD), Valparaiso University (M.Ed.), Rice University (M.M.), and Oberlin College-Conservatory (B.A./B.M.). 